\title{
Future of satellite technology being rethought everywhere?
}

Delhi \& Paris

THE partial power failure which crippled India's \$140 million multipurpose satellite, INSAT-IC, within a week of its launch by a European Ariane rocket last month has come as a blow to the Indian Space Research Organisation (ISRO). But it also highlights a growing uncertainty in the international commercial satellite market which is encouraging both manufacturers and users to look again at Earthbased telecommunications systems.

Although the cost of replacing INSATIC should be borne by its manufacturer, Ford Aerospace Corporation, its partial failure has upset India's plans to expand its national television and radio, telecommunications and meteorological networks. Fortunately, six of the satellite's twelve transponders are working perfectly, allowing a vital meteorological early-warning system to come on stream and providing back-up for INSAT-IB, which is due to be retired in mid-1989.

The future of the $\$ 350$-million INSAT system now depends solely on INSAT-ID, the last in a series of imported satellites, to be launched by a US MCDonnell-Douglas Delta rocket next year, it is hoped before INSAT-IB expires. Satellites of the INSAT-2 series, which will be bigger and heavier, will be built by ISRO and are scheduled for launch by Ariane rockets in 1990 and 1991.

Unable to expand the INSAT system as planned, an Indian interministerial committee is currently reworking communications priorities in order to make best use of INSAT-IB and the crippled INSAT-IC. But this latest failure will not only add to concern over mounting costs of India's indigenous space programme. It also adds to an increasing nervousness worldwide regarding the costs and risks of satellite technology.

Now that so many reliable civil launch vehicles are once again available - with Chinese, Japanese and Soviet launchers challenging US and European domination - it is the satellite industry itself that is being threatened. Paradoxically, this is due, on the one hand, to the long life of successful satellites and, on the other, to an increasing number of failures. India's plans to develop its own rocket launcher, already dogged by two failures in a row, may now turn out not to be viable and Prime Minister Rajiv Gandhi has ordered an in-depth review of ISRO's launch vehicle programme.

It is unlikely that India's domestic space programme will justify the cost of developing an indigenous launcher, and a stagnating world satellite market promises slim pickings even for those who already have a share. In the first half of 1987, only two satellites were ordered from major US constructors - leaders in the field compared with twelve in 1985. Current trends suggest a levelling-off of demand for civil satellites to about $10-15$ per year in the early 1990s. And if some sectors, such as direct broadcasting and telecommunications, are still expanding in Europe and Japan, improvements in long-distance fibre-optics cables are making risky satel-

\section{Court rules for demolition of West German nuclear plant}

\section{Munich}

A West German court decision has cleared the way for the demolition of a large nuclear power plant. The decision on 8 August by the Administrative Court at Regensburg rejected a citizen's claim that radiation released during demolition could endanger the local population.

Researchers at the Nuclear Research Center at Karlsruhe (KFK) are in the third year of the demolition of the nuclear power plant, owned by KFK, at Niederaichbach, near Munich. The reactor is a heavy-water-moderated, carbon dioxidecooled pressure tube reactor with $100 \mathrm{MW}$ generating capacity.

KFK will not complete demolition until 1992 at the earliest. Remote-control equipment powerful enough to move several tonnes of material will be used for the first time. Demolition will cost DM140 million. The reactor cost DM230 million and was built between 1966 and 1972 .

Niederaichbach citizen Franz Kohout began his legal challenge of the demolition in 1986. The court could have halted demolition of the reactor core, but it ruled that the amount of radiation released would not exceed the allowable level of 30 millirem per year.

Beginning in 1990 , a KFK team will dismantle up to 500 tonnes of radioactive steel and 500 tonnes of concrete from the core and shielding of the plant and pack it into shielded barrels for transport to permanent storage sites. Roughly 1,700 tonnes of waste steel that is only slightly radioactive will be recycled in Karlsruhe and used in nuclear shielding or storage containers. Fuel elements have already been removed from the plant.

Steven Dickman lite technology appear increasingly unattractive. Private sector investment in fibreoptics technology has already overtaken investment in satellite technology, even among leading satellite constructors.

Even the outwardly attractive scientific and technological advantages of a manned space platform, such as microgravity conditions, are coming under scrutiny because of the setbacks caused by the withdrawal of the US space shuttle. With a backlog of around 140 experiments planned for Spacelab, US companies are wondering whether microgravity projects will be commercially viable, and McDonnell-Douglas has already started to develop Earth-based laboratories for its revolutionary electrophoresis process.

K.S. Jayaraman \& Peter Coles

\section{South Africa states NPT conditions}

\section{Oxford}

THE South African government has declared that it would find it difficult to be a signatory to the Nuclear Non-proliferation Treaty (NPT), unless it has the right to buy and sell uranium and exchange nuclear technology internationally. In a joint statement released in Cape Town last week on their return from Vienna, Minister of Foreign Affairs Pik Botha and Minister of Technology Danie Steyn claim that these rights are implicit in the treaty. In Vienna, South Africa was urged by the Soviet Union, Britain and the United States, the main guarantors of the treaty, to accede to the NPT, thereby opening all its nuclear installations to inspection by the International Atomic Energy Agency (IAEA).

The ministers' precondition is clearly aimed chiefly at the United States, which imposed an embargo on the importation of South African uranium in January 1987, although other NPT signatories which restrict the importation of South African uranium include Norway, the Soviet Union, Canada, Australia and New Zealand. South Africa is particularly worried about its declining trade with the United States; last year, South African exports to the United States were worth just over half their average annual value between 1983 and 1985 . Even since the law was tightened up in the middle of last year, the United States still permits the importation of uranium mined in South Africa, but enriched by a third party. Similarly, the Soviets are also said to countenance the import of uranium of South African origin.

A revocation of the US ban appears extremely unlikely in the current political climate. Thus South Africa's action is likely to be seen as a red herring, particularly as it refused to sign the NPT for almost 20 years before the implementation of the ban. Michael Cherry 